\title{
The trade-off between deep energy retrofit and improving building intelligence in a university building
}

\author{
Muhyiddine Jradi, ${ }^{1 *}$ \\ ${ }^{1}$ Center for Energy Informatics, The Maersk Mc-Kinney Moller Institute, University of Southern Denmark, 5230 Odense M, \\ Denmark
}

\begin{abstract}
In the last three decades, deep energy retrofit measures have been the standard option to improve the existing Danish building stock performance, with conventional techniques including envelope constructions insulation, windows change and lights replacement. While such techniques have demonstrated large technical and economic benefits, they may not be the optimal solution for every building retrofit case. With the advancement in the field of smart buildings and building automation systems, new energy performance improvement measures have emerged aiming to enhance the building intelligence quotient. In this paper, a technical evaluation and assessment of the trade-off between implementing deep energy retrofit techniques and improving building intelligence measures is provided. The assessment is driven by energy simulations of a detailed dynamic energy performance model developed in EnergyPlus. A $2500 \mathrm{~m}^{2}$ university building in Denmark is considered as a case study, where a holistic energy model was developed and calibrated using actual data. Different performance improvement measures are implemented and assessed. Standard deep energy retrofit measures are considered, where the building intelligence improvement measures are in compliance with the European Standard EN 15232 recommendations. The overall assessment and evaluation results will serve as recommendations aiding the decision to retrofit the building and improve the performance.
\end{abstract}

\section{Introduction}

When it comes to the building sector, Denmark is not an exception as the building block contributes to a substantial $40 \%$ of the overall energy consumption share with an equivalent contribution in terms of greenhouse gas emissions [1]. Obviously, heating ranks at the top of the building services regarding energy usage, mainly to fulfil space heating and domestic hot water demands. In the recent decades, Denmark has set very ambitious, yet realistic goal to become a fossil fuel-free country by 2050 [2], relying only on alternative and renewable energy resources in the energy and transport sectors. Thus, major efforts have been devoted to improving the country energy generation and supply sectors with fields including multi-generation technologies, energy storage, innovative heat and electricity production technologies and energy storage given full consideration. However, reducing the overall energy demand is as important as enhancing the energy generation and supply sector. Therefore, a balanced approach aiming to improve energy supply stability and capacity in addition to reducing the different sectors energy usage is key towards attaining the holistic 2050 goal. In this context, designing and constructing new highly energy efficient buildings and improving the performance of the exiting building stock is a major milestone towards reducing consumption and achieving the country ambitious energy and environmental aims.

In the recent decades, the Danish building regulations, referred to as 'Danish BR', have been continuously improved and upgraded, mainly on the level of newly built buildings. Thus, the standards for buildings' design and operation have been drastically tightened, forcing strict regulations in terms of the building thermal envelope components and characteristics as well as indoor thermal comfort and air quality. In addition, guidelines have been set regarding the implementation and performance of the various building services and energy supply systems.

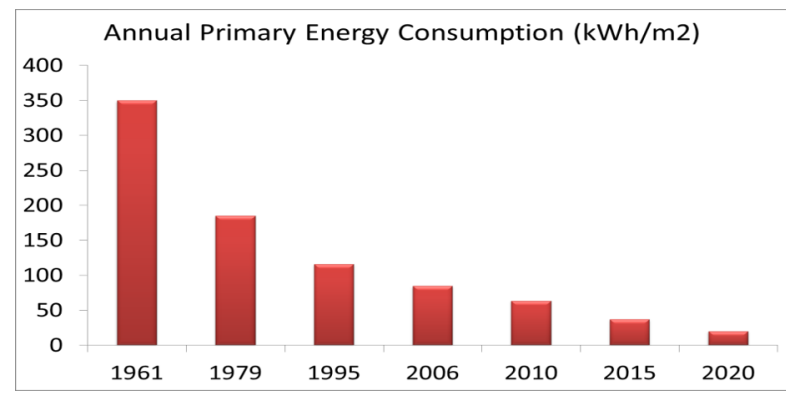

Fig. 1. The evolution of the maximum allowed annual primary energy usage for a $150 \mathrm{~m}^{2}$ residential building [3].

* Corresponding author: $\underline{\operatorname{mir} @ \text { mmmi.sdu.dk }}$ 
Figure 1 presents the evolution of the maximum allowed primary energy use for a newly built $150 \mathrm{~m}^{2}$ residential building in Denmark considering the transition between different building standards [3]. It is shown that the primary energy use falls by $95 \%$ from around $350 \mathrm{kWh} / \mathrm{m}^{2}$ per year for a building built in 1961 to only $20 \mathrm{kWh} / \mathrm{m}^{2}$ based on the future building regulation for 2020. Considering these numbers and the fact that around $80 \%$ of the Danish building stock was built before 1980, it is clear that there is a large potential to improve the overall energy performance of the exiting building stock to live up to the current standards and regulations.

While there has been a progressive tightening in the standards dealing with the design of new buildings in Denmark, less has been done in terms of organizing and promoting the existing buildings holistic energy retrofit process. Overall, the main share of the energy retrofit projects in the last three decades was driven by the need to modify or change, either on the level of envelope materials, energy systems or building services [4]. Thus, there is an absence of a systematic methodology aiding the building's retrofit decision-making. In this context, the Danish government has realized the potential of improving the overall energy performance of exiting buildings and has launched recently a comprehensive strategy: "Strategy for the energy renovation of the existing building stock" [5]. The strategy has a large set of guidelines, regulations and initiatives aiming to establish a more cost-effective, energy efficient and systematic energy retrofit projects around the country.

Considering the large energy savings potential in retrofitting exiting Danish building, a large block of research investigations and studies have been presented in the recent years, targeting various aspects of buildings energy retrofit from the theoretical and experimental perspectives. Buildings built in the $1850-1930$ period have been investigated by Odgaard et al. [6], who reported a $48 \%$ energy savings potential through adding $100 \mathrm{~mm}$ insulation to the brick exterior walls. A similar study was conducted considering a retrofit process for a multi-family building from the 1890's to comply with the 2015 Danish building regulation. The authors highlighted energy savings up to $68 \%$ through interior walls insulation, windows upgrade and mechanical ventilation system with heat recovery implementation [7]. Mørck et al. [8] reported the energy retrofit process of a school building in Ballerup, Denmark, suggesting a package of insulating the exterior wall with $33 \mathrm{~cm}$ mineral wool, adding $25 \mathrm{~cm}$ insulation to the roof, upgrading the windows to triple-glazing, installing LED lights along with a $150 \mathrm{~m}^{2}$ photovoltaic solar system. Implementing the proposed retrofit package resulted in reducing the primary energy use of the school from 200 to $75 \mathrm{kWh} / \mathrm{m}^{2}$ considering both heating and electricity. Another recent investigation by Jradi et al. [9] proposed a systematic approach for building energy retrofitting using dynamic energy performance models. Four daycare centers in Aarhus, Denmark, were considered as case study buildings, where a full scale building dynamic models were developed and various energy retrofit measures were simulated and reported. Based on the simulation results, a package of upgrading electrical equipment, installing LED lights, replacing the heating circulation pump and upgrading the ventilation system with heat recovery was chosen. The implementation yielded energy savings of around 28\%. This is accompanied by saving 5.1 tons on the annual $\mathrm{CO}_{2}$ emissions along with a 4 years payback period.

\section{Deep Energy Retrofit vs Improving Building Intelligence}

A major technique which has been implemented in the majority of energy renovation projects, especially dealing with buildings of 50 years old and more, is the deep energy retrofit (DER) approach. Such technique is generally implemented on a holistic level, targeting the building thermal envelope components as well as upgrading or changing the energy systems and devices. The MSER Building Guide [10], set by Massachusetts gas and electric utilities defines deep energy retrofit as the holistic building retrofit process targeting building enclosure and energy systems, resulting into energy efficient high performing buildings. In addition, the IEAEBC Annex 61 [11] has investigated business and technical concepts for deep energy retrofits of public buildings. As part of the investigation, an overall definition of deep energy retrofits was established as: 'Deep Energy Retrofit is a major building renovation project in which site energy use intensity, including plug loads, has been reduced by at least $50 \%$ from the prerenovation baseline'. From the technical perspective, different studies highlighted the positive impacts of implementing deep energy retrofits in existing buildings, allowing large energy savings, less greenhouse gas emissions and better thermal comfort and indoor air quality. This is in addition to the economic benefits, mainly lowering the building running and operational costs as well as limiting maintenance costs. Figure 2 depicts the results reported by Mørck et al. [12], considering 26 deep energy retrofit projects completed in different countries.

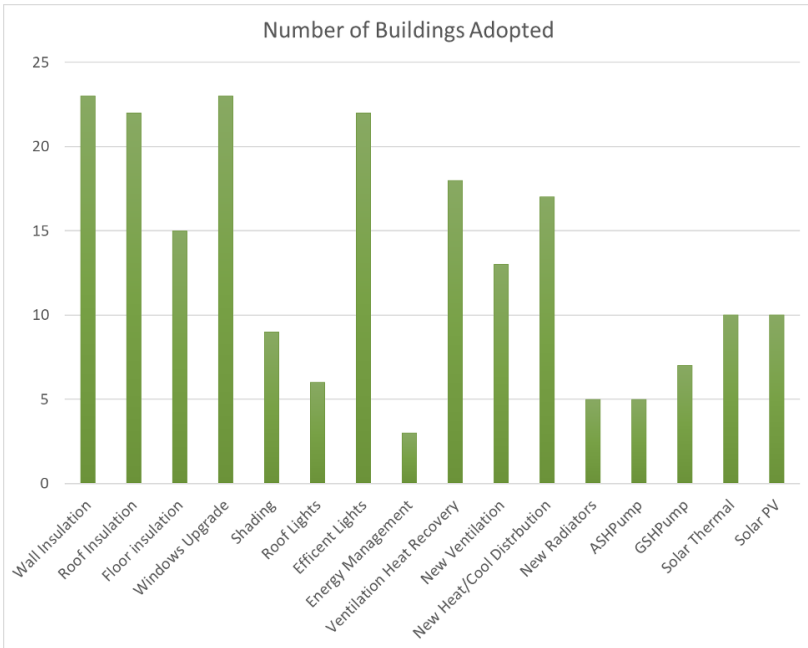

Fig. 2. Deep energy retrofit measures implemented in 26 pilot buildings [12]. 
It could be noted that physical envelope measures are the priority, almost in each case, in addition to measures targeting the ventilation, heating, cooling and lighting systems upgrade. However, measures targeting the building energy management patterns were only implemented in 3 buildings out of 26 . Speaking about energy management and improving the building intelligence quotient, intelligent buildings is an old notion which was used in the 1980's, with no common or universal definition. An early definition of intelligent buildings was provided by Leifer et al. [13], who stated that an intelligent building is a building that harness communication technology to automatically control multiple energy systems, coupled with energy use predictions and evaluations. A very widely used definition of intelligent buildings in the US is buildings that are capable of integrating different systems to effectively manage resources in an organised and coordinated mode [14]. In our work, we define building intelligence as the capability of the building to adopt automated strategies to control and manage the performance of multiple energy systems, responding to occupants demands while ensuring thermal comfort and high energy performance. In this context, we will employ the European standard EN 15232 on impact of Building Automation, Controls, and Building Management [15], as a guideline for the energy management measures to be implemented and assessed.

While deep energy retrofit techniques as envelope components upgrade, lights change and ventilation system upgrade have demonstrated large positive technical and economic impacts, they might not be the optimal solution for every retrofit project. With the advancement in the field of smart buildings and automation systems, new performance improvement measures have emerged aiming to enhance the building intelligence quotient. In this work, an overall technical assessment of the trade-off between deep energy retrofit techniques implementation and enhancing the building intelligence is performed. The evaluation is supported by dynamic energy simulations of a detailed building performance model developed in EnergyPlus. A Danish university building is considered as a case study where multiple performance improvement measures are implemented and assessed. Along with standard deep energy retrofit measures, multiple building intelligence enhancement measures are chosen, in compliance with the European Standard EN 15232 recommendations.

\section{Case Study Building}

A $2500 \mathrm{~m}^{2}$ university building is considered as a case study in this work to evaluate and assess the trade-off between deep energy retrofit and improving building intelligence. The MMMI office building, shown in Fig. 3, was opened in the 1995 and is used on a daily basis by researchers and students of the University of Southern Denmark in Odense [16]. The building has two long floors with a small basement, and constitutes mainly of 100 rooms, between offices, research rooms, laboratories, seminar and meeting rooms. The overall specifications and characteristics of the building are listed in Table 1.

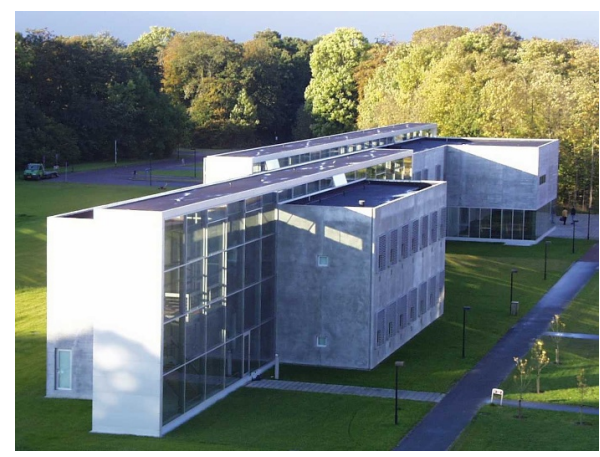

Fig. 3. MMMI office building case study.

Table 1. MMMI building specifications.

\begin{tabular}{|l|l|}
\hline Location & SDU Odense Campus \\
\hline Indoor Heated Area & $2500 \mathrm{~m}^{2}$ \\
\hline Rooms & 110 rooms \\
\hline Window to wall ratio & 0.26 \\
\hline Roof & $\begin{array}{l}300 \mathrm{~mm} \text { concrete with insulation } \\
\text { and bitumen }\end{array}$ \\
\hline Exterior Walls & $\begin{array}{l}300 \mathrm{~mm} \text { mainly concrete and } \\
\text { insulation }\end{array}$ \\
\hline Windows & Double-glazed windows \\
\hline Heating System & $\begin{array}{l}\text { In-direct district heating system } \\
\text { with a heat exchanger on the main } \\
\text { supply }\end{array}$ \\
\hline Hot Water & $\begin{array}{l}\text { Central production in an insulated } \\
\text { storage tank }\end{array}$ \\
\hline $\begin{array}{l}\text { Space Heating } \\
\text { Radiators }\end{array}$ & $\begin{array}{l}\text { Radiators in every room with } \\
\text { thermostatic valves }\end{array}$ \\
\hline Ventilation System & $\begin{array}{l}\text { Mainly natural ventilation with } \\
\text { individual mechanical ventilation } \\
\text { units in laboratories and specific } \\
\text { rooms }\end{array}$ \\
\hline Lighting & $\begin{array}{l}\text { A mix of } 100 \mathrm{~W} \text { halogen lights and } \\
\text { fluorescent lights in the offices }\end{array}$ \\
\hline Equipment & $\begin{array}{l}\text { Mainly laptops, screens, printers, } \\
\text { kitchen equipment. }\end{array}$ \\
\hline $\begin{array}{l}\text { Annual Heating usage } \\
\text { (2018) }\end{array}$ & 269.1 MWh \\
\hline $\begin{array}{l}\text { Annual Electricity } \\
\text { usage (2018) }\end{array}$ & \begin{tabular}{l}
177.8 MWh \\
\hline
\end{tabular} \\
\hline
\end{tabular}

The building thermal envelope complies with the BR1995 Danish building regulation regarding the thermal transmittance values of the various components. Windows are double-glazed, and roofs and walls are mainly made of concrete. In terms of energy systems, an in-direct district heating system with a heat exchanger on the main supply is employed to satisfy the building heating demands. In addition, domestic hot water is produced onsite in a large central tank. Natural ventilation is employed in the majority of the building, with individual mechanical ventilation units devoted to specific rooms and laboratories. Regarding energy labelling, the building is now classified as an ' $E$ ' building, with an annual heating and electricity consumption of $269 \mathrm{MWh}$ and $178 \mathrm{MWh}$ in 2018 respectively. Considering the reported numbers, there is a large potential in improving the building performance, 
on both levels, the thermal envelope components and energy systems operation and control.

\section{Building Energy Modelling and Simulation}

The energy modelling and simulation framework described by Jradi et al. [16] is adopted in this work, employing a package of tools including i) Sketchup Pro for 3D architectural drawing, ii) OpenStudio for building energy model development and iii) EnergyPlus for running energy simulations and results reporting. Using various design information and specifications, a 3D architectural model was developed for the MMMI model in Sketchup Pro with a detailed depiction of the building geometry, orientation and rooms distribution.

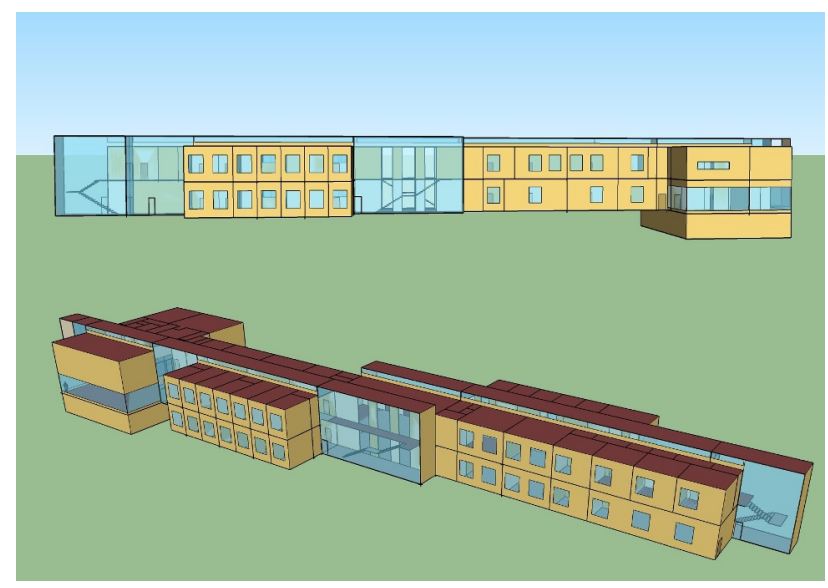

Fig. 4. MMMI office building 3D architectural model.

The 3D model, shown in Fig. 4, was imported to OpenStudio to develop the detailed holistic energy model of the building where various specifications and characteristics are defined. This includes building constructions and materials, loads, schedules, HVAC systems, lighting and equipment. In addition, onsite weather conditions and actual collected occupancy numbers and patterns were imported as part of the energy model to provide a more realistic characterization of the actual building performance. Regarding lighting and equipment schedules, default office building schedules were initially used. Then these schedules were updated using field investigations and information collected on the building use. After completing the whole building energy model development with all the specifications defined, the well-established and validated simulation engine of EnergyPlus was used to run building energy simulations and report the energy performance at various levels. Using actual data collected onsite on the building monthly energy use for heating, ventilation, lighting, equipment and overall electricity, the developed baseline building model was calibrated with a reported maximum uncertainty of $3.8 \%$ and $5.2 \%$ for monthly heating and electricity consumption respectively.

The pie chart shown in Fig. 5. provides an overview on the annual energy usage breakdown of the MMMI building. It is shown that the heating dominates the energy use scheme with around $60 \%$, followed by electric equipment and building services with $20 \%$, lighting with $12 \%$ and ventilation electricity consumption by around $8 \%$. Moreover, Fig. 6 depicts the monthly profile of the building total heating and electricity consumption as predicted by the holistic energy model. It could be seen that electricity consumption is generally stable over the year with an average use of around 14.7 MWh on a monthly basis. On the other hand, heating energy usage has an expected profile, peaking in the month of January with over 52 MWh of heating consumption.

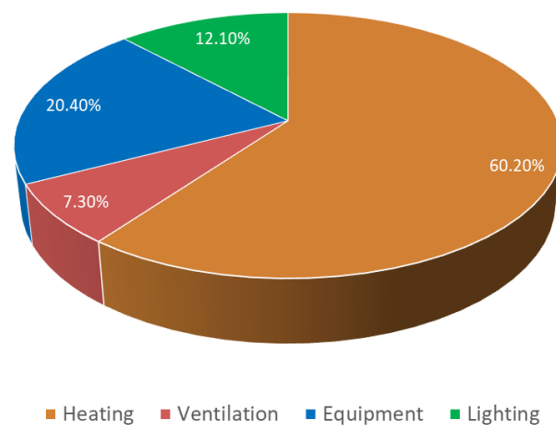

Fig. 5. Annual building energy usage breakdown.

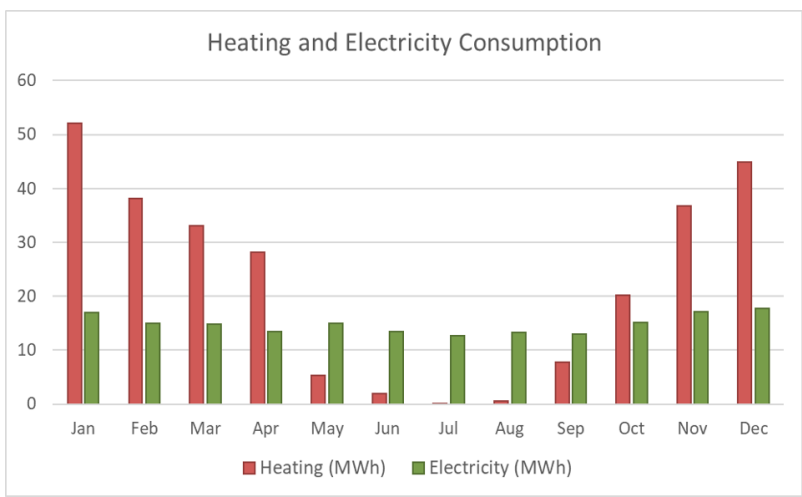

Fig. 6. Building monthly heating and electricity usage profiles.

Table 2 depicts the Danish building energy labelling system with the corresponding annual primary energy usage associated to each class. The MMMI building annual primary energy usage is calculated per indoor floor area and is also reported in Table 2. This primary energy use takes into account the overall building energy consumption for heating, ventilation and electricity, excluding equipment consumption. A weighting factor of 1 is used for heating and a factor of 2.5 is used for electricity, based on the Danish building standard recommendations. Considering the building energy usage profile for 2018, the annual primary energy use of the building in its current state is $194.2 \mathrm{kWh} / \mathrm{m}^{2}$. As shown in Table 2, for the MMMI building to comply with the acceptable energy class ' $\mathrm{C}$ ', its primary energy use should be reduced to reach $136.2 \mathrm{kWh} / \mathrm{m}^{2}$, which seems viable with effective actions. For the building to 
comply with the more strict A2010 class, around 62\% reduction on the primary energy use should be exhibited to reach the $71.9 \mathrm{kWh} / \mathrm{m}^{2}$ maximum line. Nevertheless, if a new office building of the same size as the MMMI building is to be built today, the building is allowed to consume a maximum of $41.4 \mathrm{kWh} / \mathrm{m}^{2}$ primary energy per year. Considering the numbers reported in Table 2 , it is clear that the building needs an energy upgrade retrofitting to improve the overall energy performance, reduce the energy usage, enhance its energy label and to live up to the current building energy standards.

Table 2. Danish building energy label.

\begin{tabular}{|l|c|}
\hline Energy Label & $\begin{array}{c}\text { Annual Primary Energy } \\
\text { Consumption }\left(\mathrm{kWh} / \mathrm{m}^{2}\right)\end{array}$ \\
\hline A2020 & 33.0 \\
\hline A2015 & 41.4 \\
\hline A2010 & 71.9 \\
\hline B & 95.8 \\
\hline C & 136.2 \\
\hline D & 176.6 \\
\hline E & 217.0 \\
\hline F & 267.6 \\
\hline MMMI building current state & 142.9 \\
\hline
\end{tabular}

\section{Energy Retrofit Measures}

The results reported in the previous section shows that the considered office building consumes around 194 $\mathrm{kWh} / \mathrm{m}^{2}$ per year as primary energy to satisfy heating and electricity demands. Considering the fact that the acceptable energy class for an existing building based on the Danish building regulation ' $\mathrm{BR} 18$ ' is ' $\mathrm{C}$ ', corresponding to an annual primary energy use of 136 $\mathrm{kWh} / \mathrm{m}^{2}$, it is clear that the building would be able to attain this level with effective and targeted modifications. However, to reach the more strict and energy efficient ' $A$ ' classes, a set of improvement measures are needed with the requirement to reduce around $62 \%$ of the primary energy use to reach the 71 $\mathrm{kWh} / \mathrm{m}^{2}$ line. Aiming to assess the impact of implementing various energy retrofit measures on the energy performance of the MMMI building, a set of different improvement measures are designed, implemented and simulated employing the calibrated holistic building model. The assessment is purely technical, meaning that the electricity and heating savings in each improvement case is reported in comparison to the current baseline state. The considered energy retrofit pool comprises a mix of deep energy retrofit measures targeting the building envelope and services in addition to management and automation measures dealing with various building systems to improve the building intelligence quotient. The list of considered energy improvement measures are presented in Table 3.
Table 3. List of energy improvement measures implemented.

\begin{tabular}{|c|c|c|}
\hline \multicolumn{3}{|c|}{ Energy Retrofit Measures } \\
\hline Application & No. & $\begin{array}{l}\text { Energy Improvement } \\
\text { Measure }\end{array}$ \\
\hline \multirow{12}{*}{$\begin{array}{l}\text { Deep Energy } \\
\text { Retrofit } \\
\text { Improvement } \\
\text { Measures }\end{array}$} & M1 & $\begin{array}{l}\text { Adding } 150 \mathrm{~mm} \text { exterior } \\
\text { wall insulation }\end{array}$ \\
\hline & M2 & $\begin{array}{l}\text { Adding } 200 \mathrm{~mm} \text { roof } \\
\text { insulation }\end{array}$ \\
\hline & M3 & $\begin{array}{l}\text { Adding } 200 \mathrm{~mm} \text { floor } \\
\text { insulation }\end{array}$ \\
\hline & M4 & $\begin{array}{l}\text { Installing triple-glazed } \\
\text { windows }\end{array}$ \\
\hline & M5 & $\begin{array}{c}\text { Installing energy efficient } \\
\text { windows with low } \\
\text { emissivity }\end{array}$ \\
\hline & M6 & Installing LED lights \\
\hline & M7 & $\begin{array}{l}\text { Replacing the hot water } \\
\text { circulation pump }\end{array}$ \\
\hline & M8 & $\begin{array}{l}\text { Upgrading the ventilation } \\
\text { system supply fans }\end{array}$ \\
\hline & M9 & $\begin{array}{l}\text { Adding a heat recovery unit } \\
\text { to the ventilation units }\end{array}$ \\
\hline & M10 & $\begin{array}{l}\text { Adding a pre-heating loop } \\
\text { to the ventilation units }\end{array}$ \\
\hline & M11 & $\begin{array}{l}\text { Upgrading the electrical } \\
\text { equipment and devices }\end{array}$ \\
\hline & M12 & $\begin{array}{l}\text { Installing a PV solar system } \\
\text { covering } 10 \% \text { of the } \\
\text { building roof }\end{array}$ \\
\hline \multirow{2}{*}{$\begin{array}{l}\text { Lighting System } \\
\text { Management } \\
\text { Measures }\end{array}$} & M13 & $\begin{array}{l}\text { Installing daylight sensors } \\
\text { in common and open rooms }\end{array}$ \\
\hline & M14 & Installing motion sensors \\
\hline \multirow{3}{*}{$\begin{array}{l}\text { Ventilation System } \\
\text { Management } \\
\text { Measures }\end{array}$} & M15 & $\begin{array}{l}\text { Implementing } \mathrm{CO}_{2} \text {-based } \\
\text { ventilation control }\end{array}$ \\
\hline & M16 & $\begin{array}{l}\text { Implementing temperature- } \\
\text { based ventilation control }\end{array}$ \\
\hline & M17 & $\begin{array}{c}\text { Implementing a mix of } \\
\mathrm{CO}_{2} \text { - and temperature-based } \\
\text { ventilation control strategy }\end{array}$ \\
\hline \multirow{2}{*}{$\begin{array}{l}\text { Heating System } \\
\text { Management } \\
\text { Measures }\end{array}$} & M18 & $\begin{array}{l}\text { Implementing heating } \\
\text { setpoint management }\end{array}$ \\
\hline & M19 & $\begin{array}{l}\text { Implementing adaptive } \\
\text { heating control for weather } \\
\text { compensation }\end{array}$ \\
\hline
\end{tabular}

In total, a set of 19 building energy performance improvement measures are considered. As divided in Table 3, the improvements set includes deep energy retrofit, lighting system management, ventilation system management and heating system management measures. Twelve deep energy retrofit measures are included, considering conventional standard Danish buildings energy improvement techniques. This comprises building exterior walls and roofs insulation, windows upgrade, LED implementation, PV system installation in 
addition to various energy systems components and devices upgrade.

The deep energy retrofit measures are in compliance with the Danish building regulation BR18 recommendations regarding building envelope and energy systems. On the other hand, the rest of the measures aiming to control and manage the operation of various energy systems in the building are considered based on the guidelines of the European Standard EN 15232, dealing with "Energy performance of buildings Impact of Building Automation, Controls and Building Management" and aiming to enhance the building intelligence quotient. These energy management measures are divided into three categories, measures targeting the lighting system, the ventilation system and the heating system, being the major energy systems and units in the considered MMMI case study building.

The European Standard EN 15232 is the official regulation targeting building automation systems in the EU, developed as a support for the upgraded EU Energy Performance of Building Directive (EPBD). The standard comprises methods, strategies and guidelines for building automation and control systems (BACS) auditing, evaluation and assessment. In specific, a set of automation, control and technical management functions are included for each building service domain aiming to enhance the operation and improve the overall building intelligence and management level, including heating, cooling, lighting and ventilation systems. Four energy efficiency classes are defined by the EU 15232 standard, where ' $A$ ' is a highly energy efficient and fully automated and controlled building with a building automation system of high performance, and ' $\mathrm{D}$ ' is a building with no building automation system or is equipped with an automation system of minimal features. In addition, generic suggested energy efficiency factors for various building types are provided, which highlights how much energy is to be saved when moving from a lower class to a higher one. In overall, BACS class ' $\mathrm{C}$ ' is regarded as an acceptable and a standard class for existing buildings in terms of building automation and control. Although the considered MMMI building has a building management system implemented, the features and roles of this system is only exposed on a centralized level, meaning that there is no control and management on the operation of the single energy systems on a zone level. For this reason, the building is placed under BACS efficiency class ' $\mathrm{C}$ ' in its current state.

\section{Results and Discussion}

The considered energy retrofit measures are designed, implemented and simulated using the developed dynamic building energy model. Considering the simulation results, the impact of each improvement measure on the overall MMMI building performance in terms of heating and electricity consumption is reported and compared to the base case scenario. Figures 7 and 8 present the percentage of heating and electricity consumption saved on an annual basis due to the implementation of each of the 19 different energy retrofit measures considered and simulated. Based on the results reported, it is clear that there is a large variation in the impact of each improvement measure on both the heating and electricity profile of the MMMI building.

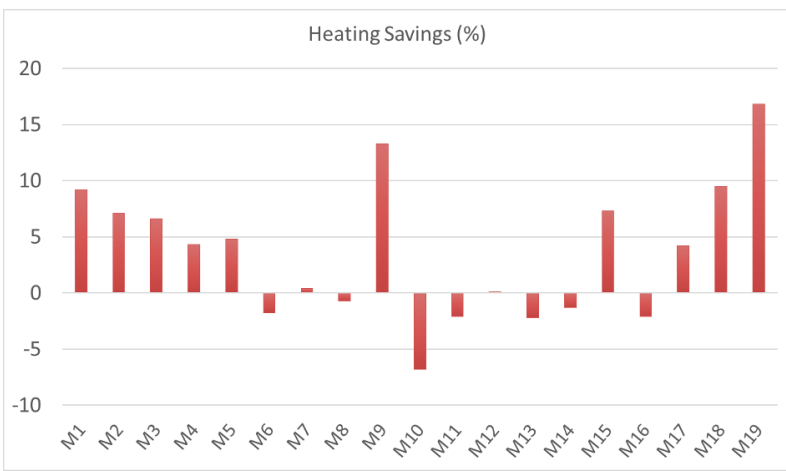

Fig. 7. Heating savings for each retrofit measure

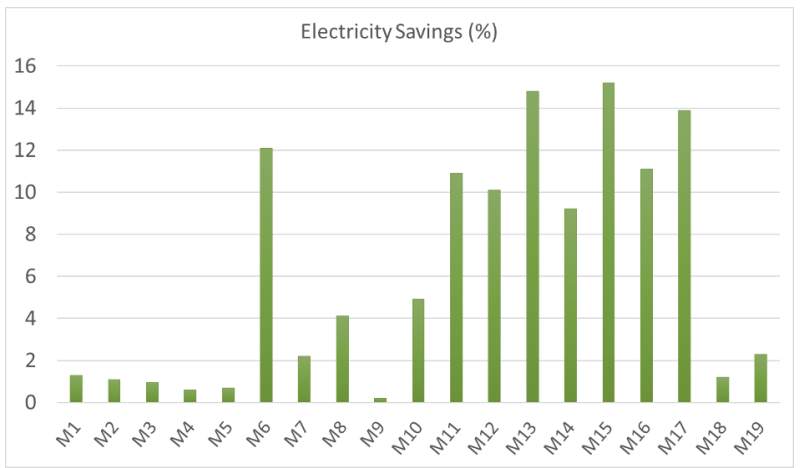

Fig. 8. Electricity savings for each retrofit measure

While all retrofit measures resulted in electricity savings, the case is different from the heating consumption perspective as 7 out of the 19 measures lead to an increase in the heating consumption. Saying that, this increase is not major and varies from $0.7 \%$ to $6.8 \%$ of the overall building heating consumption, with the addition of a pre-heating loop to the ventilation units resulting in the maximum addition on the heating demand. Improvement measures as installing LED lights and upgrading the building electrical equipment and devices also lead to a slight increase in the heating consumption, mainly due to the fact that energy efficient lights and equipment are characterized with lower rates of heat loss inside the building compared to conventional devices. In terms of reducing the heating demand, two measures stand out: adding a heat recovery unit to the ventilation systems and implementing adaptive heating control for weather compensation with a respective heating savings of $13.3 \%$ and $16.8 \%$. Deep energy retrofit targeting the building thermal envelope including insulation of constructions and upgrading windows resulted in heating savings ranging from $4 \%$ to $9 \%$. An interesting point is noted as some energy management measures allows comparable heating savings as upgrading the building envelope, including heating setpoint management with $9.5 \%$ and implementing $\mathrm{CO}_{2}$ - 
based ventilation system control with around 7.3\% reduction on the heating demand.

On the other hand, a different technical impact of the implemented measures is reported on the building electricity consumption profile. The improvement measures allowing the highest savings on the building electricity consumption are mostly measures targeting building systems management and control. This includes implementing $\mathrm{CO}_{2}$-based ventilation control with $15.2 \%$, installing daylight sensors in common and open rooms with $14.8 \%$ and implementing a mix of $\mathrm{CO}_{2-}$ and temperature-based ventilation system control strategy with $13.9 \%$ reduction on the electricity demand. Nevertheless, deep retrofit measures targeting upgrading building lights and electrical equipment allows an average of $11 \%$ electricity savings. In addition, it is noted that measures as replacing hot water circulation pumps, upgrading ventilation system fans and managing the heating system setpoint scheme allows a small reduction on the electricity use $(1.2 \%$ to $4.1 \%)$. However, if the technical assessment presented is coupled with an economic evaluation, such measures would emerge as favourable due to being simple to implement with minimal investment costs compared to other measures along with a lower payback period.

Considering the results of the single improvement measures implementation in the building, two holistic retrofit packages were designed and implemented in the dynamic building model. The aim of the packages' implementation is to assess and compare the impact of choosing to go with deep energy retrofit measures or going with a package targeting building energy systems management to enhance the building intelligence quotient. The two investigated packages are as follows:

- Retrofit Package A (RPA): A deep energy retrofit package comprising a set of measures targeting building physical envelope enhancement and various components upgrade. The measures listed under Package A are exterior wall insulation, roof insulation, floor insulation, triple-glazed windows, LED lights installation, upgraded water circulation pumps, new ventilation supply fans, ventilation heat recovery unit and pre-heating loop addition and electrical equipment and devices upgrade.

- Retrofit Package B (RPB): An energy management and building automation package with measures targeting improving various building energy systems operation through effective management and control schemes. The measures listed under Package B are daylight sensors installation in common and open rooms, motion sensors addition, $\mathrm{CO}_{2}$-based ventilation control implementation, heating system setpoint management, adaptive heating control implementation and PV solar system installation.

The two retrofit packages, RPA and RPB, are implemented and defined in the dynamic energy building model and a yearly energy performance simulation of the MMMI building is performed to report the technical impacts of the two packages on the building operation and on the holistic energy usage profiles. Figure 9 shows the impact of retrofit packages A and B on the MMMI energy usage profile as predicted by the dynamic building model. It is shown that the deep energy retrofit package (RPA) yields larger savings on the heating consumption and equipment electricity consumption, while the energy management package (RPB) allows more savings on the electricity consumption for ventilation and lighting consumption in the case study building.

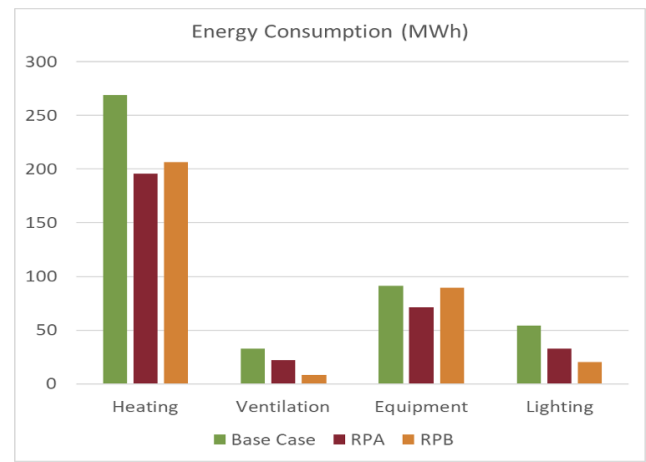

Fig. 9. The impact of retrofit packages A and B on the MMMI energy consumption profile

On a holistic level, RPA implementation reduces the energy usage for heating by $27.2 \%$ and the overall building electricity use by $29.1 \%$. Comparably, RPB yields overall heating and electricity savings of around $23.3 \%$ and $33.8 \%$ respectively. While RPB have relatively less impact on the building heating profile compared to RPA, implementing the energy management package RPB allows a substantial reduction on the building ventilation electricity consumption of $71 \%$ and lighting consumption of around $60 \%$. This is mainly due to the effective energy management and control strategies implemented as part of the retrofit package.

Table 4 provides a summary on the impact of the two retrofit packages on the building annual primary energy use. Overall, the deep energy retrofit package RPA allows reducing the annual primary energy usage of the building to $132.7 \mathrm{kWh} / \mathrm{m}^{2}$, while the building energy management package RBP without the PV system implementation allows further reduction on the primary energy consumption to $111.1 \mathrm{kWh} / \mathrm{m}^{2}$. With these numbers, both packages allow enhancing the building energy class to comply with the ' $\mathrm{C}$ ' level of the Danish building regulation. Furthermore, adding a PV solar system covering $10 \%$ of the building roof area as part of the RPB retrofit package allows a drastic reduction on the building annual primary energy usage to reach 93 $\mathrm{kWh} / \mathrm{m}^{2}$ with a substantial reduction of around $52.1 \%$ compared to the current MMMI building case. One additional added value in terms of implementing the energy management package RPB is raising the building energy efficiency class according to the EN 152323 BACS building automation standard from Class ' $C$ ' to Class 'B', considering the strategies implemented targeting energy systems operation and building intelligence. 
Table 4. Impact of RPA and RPB packages on the primary energy usage.

\begin{tabular}{|l|c|}
\hline & $\begin{array}{c}\text { Annual Primary Energy } \\
\text { Usage }\left(\mathrm{kWh} / \mathrm{m}^{2}\right)\end{array}$ \\
\hline Base Case & 194.2 \\
\hline RPA & 132.7 \\
\hline RPB with no PV system & 111.1 \\
\hline RPB with PV system & 93.0 \\
\hline
\end{tabular}

\section{Conclusion}

In this paper, a technical evaluation and assessment of the trade-off between implementing deep energy retrofit techniques and improving building intelligence measures is provided. The holistic assessment and evaluation provided is driven by dynamic energy simulations of a detailed building performance model developed in EnergyPlus. As a case study, a $2500 \mathrm{~m}^{2}$ university building situated in Odense, Denmark, is considered to evaluate energy improvement scenarios. A holistic dynamic energy model of the building is developed and calibrated using actual collected data onsite. Then, a list of energy improvement measures is implemented and simulated using the calibrated model to evaluate the impact on the heating and electricity consumption profiles. The set of measures comprise both, deep energy retrofit measures and energy management measures. It was shown that adding a heat recovery unit to the ventilation system and implementing adaptive heating control for weather compensation provide the highest impact on the heating savings with $13.3 \%$ and $16.8 \%$ respectively. On the other hand, implementing $\mathrm{CO}_{2}-$ based ventilation control and installing daylight sensors in common rooms yield the largest savings on electricity consumption with $14.8 \%$ and $15.2 \%$. Overall, the results show that energy management measures have comparable energy savings and, in some cases, higher impact when compared to deep energy retrofit measures targeting building envelope or upgrading components.

Nevertheless, two packages were considered for further evaluation, RPA deep energy retrofit package and RPB energy management and building automation package. While RPA yields higher heating savings, RPB allows saving $23 \%$ and $33 \%$ on the heating and electricity demand respectively. Moreover, implementation of the RBP package along with a PV system installation allows reducing the annual primary energy usage by $52 \%$. The reported results show that conventional deep energy retrofit techniques including envelope components insulation, windows change, and lights replacement are not the optimal solution for every building retrofit case. It is also demonstrated that energy management techniques, which could have the edge from the economic perspective, would yield comparable savings in terms of heating and electricity consumption. In summary, the trade-off between implementing deep energy retrofit techniques and improving building intelligence measures is governed by many factors. This includes building type and age, energy systems installed, building automation level, thermal envelope status in addition to the technical and economic feasibility. While this study deals with a holistic technical assessment of the different scenarios, an overall economic assessment is vital on a case by case basis to aid the retrofit project decision-making.

This work was supported by the BuildCOM project, funded by the Danish Energy Agency under the Energy Technology Development and Demonstration Program (EUDP), ID number: 64019-0081.

\section{References}

1. M. Jradi, K. Arendt, F.C. Sangogboye, C.G. Mattera, E. Markoska, M.B. Kjærgaard, C.T. Veje, B.N. Jørgensen, Energy Build. 166, 196-209 (2018).

2. H. Lund, B.V. Mathiesen, Energy 34, 524-531 (2009).

3. Energy Policy Toolkit on Energy Efficiency in New Buildings - Experiences from Denmark, The Danish Energy Agency, (2015). https://ens.dk/sites/ens.dk/files/Globalcooperation/to ol_ee_byg_web.pdf.

4. A. Jafari, V. Valentin, Build. Environ. 115, 118-129 (2017).

5. Strategy for energy renovation of Buildings, Danish Ministry of Climate, Energy and Building. https:/ec.europa.eu/energy/sites/ener/files/document s/2014_article4_en_denmark.pdf, May (2014).

6. T. Odgaard, S.P. Bjarløv, C. Rode, M. Vesterløkke, Energy Procedia 78, 830-835 (2015).

7. M. Morelli, L. Rønby, S.E. Mikkelsen, M.G. Minzari, T. Kildemoes, H.M. Tommerup, Energy Build. 54, 395-406 (2012).

8. O. Morck, K.E. Thomsen , B.E. Jorgensen, Energy Procedia 78, 3324-3329 (2015).

9. M. Jradi, B.N. Jorgensen, C.T. Veje, Energy Build. 158, 62-76 (2018).

10. Mass Save deep energy retrofit builder guide, Building Science Corportation (2013). https://buildingscience.com/documents/guidesandmanuals/gm-mass-save-der-builder-guide/view.

11. A. Zhivov, H. Staller, R. Lohse, O. Moerck, J. Shonder, M. Nokkala, C. Nasseri, ASHRAE Trans. 121, 111-129 (2015).

12. O.C. Mørck, M.S. Gutiérrez, A.M. Zhivov, R. Lohse, Proceedings of the 12th REHVA World Congress - CLIMA 2016, Aalborg, Denmark, May 22-25, 2016.

13. D. Leifer, Architecture Australia 77, 200-202 (1988)

14. A. GhaffarianHoseini, Intelligent Buildings International 4, 34-48 (2012).

15. European Technical Standard EN 15232, Energy Performance of Buildings-Impact of Building Automation, Control, and Building Management, (2nd ed.), CEN, Brussels (2012).

16. M. Jradi, C. Veje, B.N. Jørgensen, Energy Build. 151, 306-319 (2017). 